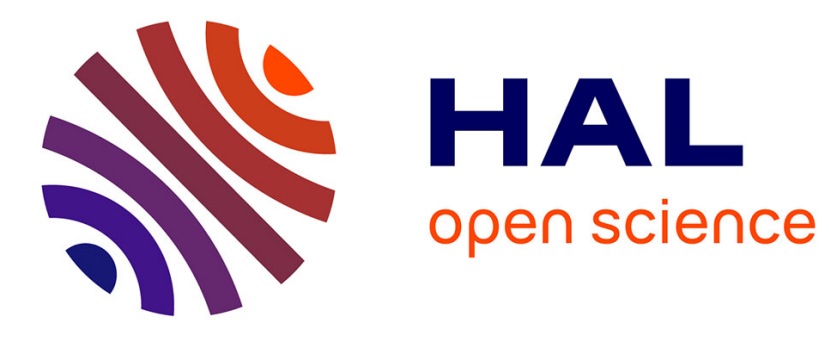

\title{
Half-sandwich molybdenum compounds with phosphine-alkylthiolate and phosphine-thioether ligands. Crystal structure of [CpMo(SCH2CH2PPh2)2][BPh4]
}

Dolores Morales, Rinaldo Poli, Philippe Richard, Jacques Andrieu, Edmond Collange

\section{To cite this version:}

Dolores Morales, Rinaldo Poli, Philippe Richard, Jacques Andrieu, Edmond Collange. Half-sandwich molybdenum compounds with phosphine-alkylthiolate and phosphine-thioether ligands. Crystal structure of $[\mathrm{CpMo}(\mathrm{SCH} 2 \mathrm{CH} 2 \mathrm{PPh} 2) 2][\mathrm{BPh} 4]$. Journal of the Chemical Society Dalton Transactions, 1999, 1999 (6), pp.867-874. 10.1039/A809903K . hal-03305051

\section{HAL Id: hal-03305051 \\ https://hal.science/hal-03305051}

Submitted on 4 Oct 2021

HAL is a multi-disciplinary open access archive for the deposit and dissemination of scientific research documents, whether they are published or not. The documents may come from teaching and research institutions in France or abroad, or from public or private research centers.
L'archive ouverte pluridisciplinaire $\mathbf{H A L}$, est destinée au dépôt et à la diffusion de documents scientifiques de niveau recherche, publiés ou non, émanant des établissements d'enseignement et de recherche français ou étrangers, des laboratoires publics ou privés. 


\section{Half-sandwich molybdenum compounds with phosphine-alkylthiolate and phosphine-thioether ligands. Crystal structure of $\left[\mathrm{CpMo}\left(\mathrm{SCH}_{2} \mathrm{CH}_{2} \mathrm{PPh}_{2}\right)_{2}\right]\left[\mathrm{BPh}_{4}\right]$}

Dolores Morales, Rinaldo Poli*, Philippe Richard, Jacques Andrieu and Edmond Collange

Laboratoire de Synthèse et d'Electrosynthèse Organométalliques, Faculté des Sciences "Gabriel”, Université dé Bourgogne, 6 Boulevard Gabriel, 21100 Dijon, France

Correspondence to: Prof. Rinaldo Poli

Laboratoire de Synthèse et d'Electrosynthèse Organometalliques

Faculté des Sciences "Gabriel"

6, Boulevard Gabriel

21100 Dijon (France)

tel: $+33-03.80 .39 .68 .81$

fax: $+33-03.80 .39 .60 .98$

E-mail: poli@u-bourgogne.fr 


\begin{abstract}
The reaction of $\mathrm{CpMoCl}_{2}$ with $\mathrm{Ph}_{2} \mathrm{PCH}_{2} \mathrm{CH}_{2} \mathrm{SR}\left(\mathrm{R}=\mathrm{H}, \mathrm{CH}_{3}\right)$ yields the corresponding addition products $\mathrm{CpMoCl}_{2}\left(\mathrm{Ph}_{2} \mathrm{PCH}_{2} \mathrm{CH}_{2} \mathrm{SR}\right.$ ), but only the derivative with $\mathrm{R}=\mathrm{CH}_{3}$ (compound 5) is sufficiently stable to be isolated as a crystalline solid. The derivative with $\mathrm{R}=\mathrm{H}$ evolves rapidly to afford a mixture of compounds $\left[\mathrm{CpMo}\left(\mathrm{SCH}_{2} \mathrm{CH}_{2} \mathrm{PPh}_{2}\right)_{2}\right]^{+} \mathrm{Cl}^{-}, \mathbf{1}$, and $\left[\mathrm{CpMoCl}\left(\mathrm{SCH}_{2} \mathrm{CH}_{2}{ }^{-}\right.\right.$ $\left.\left.\mathrm{PPh}_{2}\right)\right]_{2}, \mathbf{2}$, the former being favored by a larger ligand/Mo ratio. Compound $\mathbf{1}$ undergoes metathesis with $\mathrm{NaBPh}_{4}$ to afford $\left[\mathrm{CpMo}\left(\mathrm{SCH}_{2} \mathrm{CH}_{2} \mathrm{PPh}_{2}\right)_{2}\right]^{+} \mathrm{BPh}_{4}{ }_{4}, 3$, which has been characterized by X-ray crystallography. The reaction of $\mathrm{CpMoCl}_{2}$ with 2 equiv of $\mathrm{Ph}_{2} \mathrm{PCH}_{2} \mathrm{CH}_{2} \mathrm{~S}^{-} \mathrm{Li}^{+}$affords the paramagnetic complex $\mathrm{CpMo}\left(\mathrm{SCH}_{2} \mathrm{CH}_{2} \mathrm{PPh}_{2}\right)_{2}$, 4, which is readily oxidized by $\mathrm{Cp}_{2} \mathrm{Fe}^{1}$ or by $\mathrm{H}^{+}$to the corresponding cation. The salts $\mathbf{1}$ and $\mathbf{3}$, in turn, may be reduced by $\mathrm{Na}$ amalgam, $\mathrm{MeLi}$, or $\mathrm{Bu}^{\mathrm{t}} \mathrm{OK}$ to compound 4. The reversible redox process interconverting 4 and its cation occurs at $E_{1 / 2}=-1.23 \mathrm{~V}$ relative to the ferrocene standard, while compound 5 shows a reversible oxidation process at $E_{1 / 2}=0.12 \mathrm{~V}$ by cyclic voltammetry. The comparison between these potentials and that previously reported for $\mathrm{CpMoCl}_{2}(\mathrm{dppe})$ indicates relative donor abilities in the order $\mathrm{Ph}_{2} \mathrm{P}>\mathrm{MeS}$ and $\mathrm{RS}^{-}>\mathrm{Cl}^{-}$. Compound 5 can also be synthesized by $\mathrm{Na}$ amalgam or $\mathrm{Zn}$ reduction of $\mathrm{CpMoCl}_{4}\left(\mathrm{Ph}_{2} \mathrm{PCH}_{2} \mathrm{CH}_{2} \mathrm{SCH}_{3}\right) \mathbf{6}$, which is obtained by addition of the ligand to $\mathrm{CpMoCl}_{4}$.
\end{abstract}

\title{
Introduction
}

Molybdenum complexes with sulfide, thiolate, or thioether ligands are extensively used models for understanding the mechanism of action of fossil fuel hydrotreating catalysts and metalloenzymes involved in the nitrogen cycle. ${ }^{1-10}$ In both areas, useful information has been obtained from fundamental investigations of the effect of the coordination environment on the stability, redox properties, and reactivity. A great many studies have been devoted to dinuclear half-sandwich complexes of Mo(III) and Mo(IV),${ }^{6,7,10}$ generally containing only anionic ligands (halides, thiolates, sulfide) or a combination of these and neutral p-acceptor ligands (carbonyl, isocyanides, thioethers). In our laboratory, we have investigated in detail reactivity and redox properties as a function of the ligands for a class of mononuclear complexes of formula $\mathrm{CpMoX}_{2} \mathrm{~L}_{2}$ where $\mathrm{X}$ is a halide ligand and $\mathrm{L}$ is typically a tertiary phosphine. ${ }^{11-18}$ These are stable paramagnetic compounds characterized by a 17-electron configuration and sharp room temperature isotropic EPR resonances. We extend in this contribution the above class to thiolate and thioether derivatives. 


\section{Results}

\section{Reactions with the $\mathrm{Ph}_{2} \mathrm{PCH}_{2} \mathrm{CH}_{2} \mathrm{SH}$ ligand.}

The reaction between $\mathrm{CpMoCl}_{2}$ and the bifunctional ligand $\mathrm{Ph}_{2} \mathrm{PCH}_{2} \mathrm{CH}_{2} \mathrm{SH}$ in a $1: 1$ or $1: 2$ ratio produces compounds $\left[\mathrm{CpMo}\left(\mathrm{SCH}_{2} \mathrm{CH}_{2} \mathrm{PPh}_{2}\right)_{2}\right] \mathrm{Cl}, \mathbf{1}$, and $\left[\mathrm{CpMoCl}\left(\mathrm{SCH}_{2} \mathrm{CH}_{2} \mathrm{PPh}_{2}\right)\right]_{2}, 2$ (eq 1). The interaction initially affords an EPR active intermediate which disappears within a few minutes. The EPR properties of this intermediate indicate its probable composition as the addition product, $\mathrm{CpMoCl}_{2}\left(\mathrm{Ph}_{2} \mathrm{PCH}_{2} \mathrm{CH}_{2} \mathrm{SH}\right)$, by comparison with those of the stable thioether analogue $\mathrm{CpMoCl}_{2}\left(\mathrm{Ph}_{2} \mathrm{PCH}_{2} \mathrm{CH}_{2} \mathrm{SCH}_{3}\right)$, compound 5, see below. When a larger excess of the ligand was used (3.5 equivalents), however, compound 1 was recovered in a greater yield (57 $\%$ relative to $40 \%$ when 2 equiv were used) and product 2 was absent. The yield of compound 1 was even lower (20\%) when using a 1:1 Mo:ligand ratio.

\section{$\mathrm{CpMoCl}_{2}+\mathrm{Ph}_{2} \mathrm{CH}_{2} \mathrm{CH}_{2} \mathrm{SH} \rightarrow$}

$$
\left[\mathrm{CpMo}\left(\mathrm{SCH}_{2} \mathrm{CH}_{2} \mathrm{PPh}_{2}\right)_{2}\right] \mathrm{Cl}+\left[\mathrm{CpMoCl}\left(\mathrm{SCH}_{2} \mathrm{CH}_{2} \mathrm{PPh}_{2}\right)\right]_{2}
$$

\section{1}

Compound 1, which is obtained as a yellow precipitate from the reaction mixture, is insoluble in all common solvents and only slightly soluble in $\mathrm{MeOH}$. A ${ }^{31} \mathrm{P}\left\{{ }^{1} \mathrm{H}\right\}-\mathrm{NMR}$ spectrum in $\mathrm{MeOH}$ shows a single resonance at $\delta$ 85.1, indicating its diamagnetic nature. Metathesis of $\mathbf{1}$ with $\mathrm{NaBPh}_{4}$ yields a more soluble tetraphenylborate salt, 3, which was amenable to a more detailed characterization. The ${ }^{31} \mathrm{P}\left\{{ }^{1} \mathrm{H}\right\}$ NMR resonance of $\mathbf{3}$ compares with that of 1 , while the triplet ${ }^{1} \mathrm{H}$ NMR resonance for the $\mathrm{Cp}$ ring at $\delta 4.40\left(J_{\mathrm{HP}}=1.83 \mathrm{~Hz}\right)$ is direct evidence for the presence of two ligands per metal atom. These spectral data suggest a fourlegged piano stool structure for the cation, leaving uncertain the stereochemistry (cis vs. trans). The trans configuration is shown by the X-ray structural characterization (see below).

Compound $\mathbf{2}$ is obtained as a microcrystalline brown solid by diffusion of pentane into the $\mathrm{CH}_{2} \mathrm{Cl}_{2}$ solution after separation of compound $\mathbf{1}$. This compound is insoluble in hydrocarbon solvents but soluble in $\mathrm{CH}_{2} \mathrm{Cl}_{2}, \mathrm{CHCl}_{3}$ and THF. Elemental analyses $(\mathrm{C}, \mathrm{H}, \mathrm{S})$ and NMR investigations $\left({ }^{1} \mathrm{H}\right.$ and $\left.{ }^{31} \mathrm{P}\right)$ help in the structural assignment of the compound. The doublet $\mathrm{Cp}$

resonance in the ${ }^{1} \mathrm{H}$ NMR spectrum indicates the presence of only one ligand per metal atom and the diamagnetism requires a dimeric formulation, since mononuclear half-sandwich 
Mo(III) complexes are paramagnetic and EPR active. ${ }^{17}$ A saturated electronic configuration can be reached by adopting a bridged structure with a metal-metal bond, as described for the isoelectronic complex $\left\{\left[\mathrm{CpMo}\left(\mu-\mathrm{SBu}^{\mathrm{t}}\right)(\mathrm{CO})_{2}\right]_{2}\right\}^{2+} \cdot{ }^{19}$ In principle, either the two chloride ligands or the two thiolate functions may occupy the bridging positions. The superior bridging ability of thiolates relative to halides lead us to propose structure $\mathbf{I}$ for compound $\mathbf{2}$. The isoelectronic $\mathrm{Mo}(\mathrm{III})$ complexes $[\mathrm{CpM}(\mathrm{SMe}) \mathrm{X}(\mathrm{CO})]_{2}(\mathrm{M}=\mathrm{Mo}, \mathrm{W} ; \mathrm{X}=\mathrm{Cl}, \mathrm{Br})$ have also been proposed to adopt a thiolato-bridged structure with terminal halide ligands, ${ }^{20}$ and complexes with bridging thiolato or hydrosulfide and terminal chlorides are known for other metals. ${ }^{21,22}$ The single ${ }^{31} \mathrm{P}\left\{{ }^{1} \mathrm{H}\right\}$ NMR resonance at $\delta 78.5$ indicates the equivalence of the two phosphorus atoms and the chelating nature of the ligand, but cannot distinguish between the P:S and the $\mathrm{P}:(\mu-S)$ binding modes. Unfortunately, suitable crystals for an X-ray investigation could not be obtained.

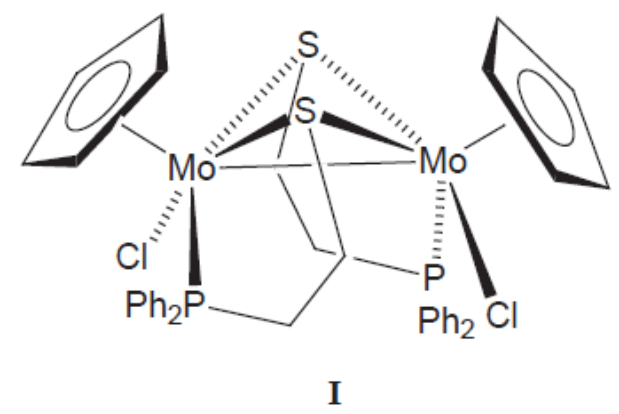

The reaction between $\mathrm{CpMoCl}_{2}$ and one equivalent of $\mathrm{Ph}_{2} \mathrm{PCH}_{2} \mathrm{CH}_{2} \mathrm{~S}^{-} \mathrm{Li}^{+}$leads to a mixture of unidentified paramagnetic products. However, the reaction with two equivalents of the same reagent produces a stable paramagnetic Mo(III) compound, namely $\mathrm{CpMo}\left(\mathrm{SCH}_{2} \mathrm{CH}_{2} \mathrm{PPh}_{2}\right)_{2}$, 4, see equation 2. Compound 4 also forms upon treatment of compound 2 with $\mathrm{Ph}_{2} \mathrm{PCH}_{2} \mathrm{CH}_{2} \mathrm{SLi}^{+}$, see equation 3. The identity of this complex as a 17electron monomer is confirmed by the EPR spectrum which shows a binomial triplet $(g=1.987$, $a_{\mathrm{P}}=3.9 \mathrm{G}, a_{\mathrm{Mo}}=32.3 \mathrm{G}$ ) in hexane (other solvents yield a broader resonance which does not permit the observation of the phosphorus coupling). It is interesting to remark the unusually small phosphorus hyperfine coupling. In previously reported bis-phosphine dichloro complexes of half-sandwich Mo(III), the $a_{\mathrm{P}}$ values are smaller when the two $\mathrm{P}$ donors adopt a relative trans configuration (in the 9-16 G range) than when they are located cis to each other (greater than $23 \mathrm{G}){ }^{12,14,23}$ A trans geometry seems therefore most reasonable for compound 4.

$\mathrm{CpMoCl}_{2}+2 \mathrm{Ph}_{2} \mathrm{PCH}_{2} \mathrm{CH}_{2} \mathrm{~S}^{-} \mathrm{Li}^{+} \rightarrow \mathrm{CpMo}\left(\mathrm{SCH}_{2} \mathrm{CH}_{2} \mathrm{PPh}_{2}\right)_{2}+2 \mathrm{LiCl}$ 
$\left[\mathrm{CpMoCl}\left(\mathrm{SCH}_{2} \mathrm{CH}_{2} \mathrm{PPh}_{2}\right)\right]_{2}+2 \mathrm{Ph}_{2} \mathrm{PCH}_{2} \mathrm{CH}_{2} \mathrm{~S}^{-} \mathrm{Li}^{+} \rightarrow$

$2 \mathrm{CpMo}\left(\mathrm{SCH}_{2} \mathrm{CH}_{2} \mathrm{PPh}_{2}\right)_{2}+2 \mathrm{LiCl}$

4

This compound can be also synthetized by reduction of compounds $\mathbf{1}$ and $\mathbf{3}$, eq. 4. The reduction of the THF-soluble 3 can be easily accomplished with sodium, while the reduction of the insoluble 1 can conveniently be carried out by the use of THF-soluble reducing agents. One such reagent is MeLi, which is known to display single electron transfer properties. ${ }^{24}$ The reduction process with this reagent is instantaneous in THF. Somewhat surprisingly, a clean reduction process also occurs, albeit more slowly (12 h), with Bu ${ }^{\mathrm{t} O K}$. Conversely, compound 4 can be chemically oxidized to the corresponding cation by a ferricinium salt, $\left[\mathrm{Cp}_{2} \mathrm{Fe}\right] \mathrm{BF}_{4}$ or by the proton of $\mathrm{HBF}_{4} \cdot \mathrm{OEt}_{2}$, as shown by EPR and NMR spectroscopic monitorings. The oxidation with $\mathrm{HBF}_{4} \cdot \mathrm{OEt}_{2}$ in $\mathrm{C}_{6} \mathrm{D}_{6}$ led to the immediate evolution of $\mathrm{H}_{2}$, which was identified by the characteristic NMR resonance at $\delta 4.5$.

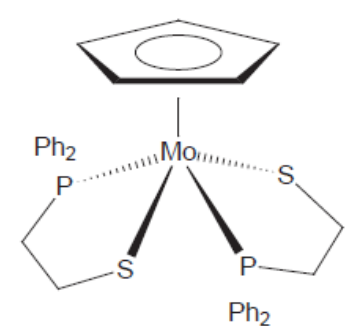

4

(i) $\left[\mathrm{Cp}_{2} \mathrm{Fe}_{\mathrm{BF}}\right.$ or $\mathrm{HBF}_{4} \quad\left(\mathrm{X}=\mathrm{BF}_{4}\right)$

(ii) $\mathrm{Na}\left(\mathrm{X}=\mathrm{BPh}_{4}\right)$ or $2 \mathrm{MeLi}(\mathrm{X}=\mathrm{Cl})$ or $\mathrm{Bu}^{\mathrm{t}} \mathrm{OK}(\mathrm{X}=\mathrm{Cl})$

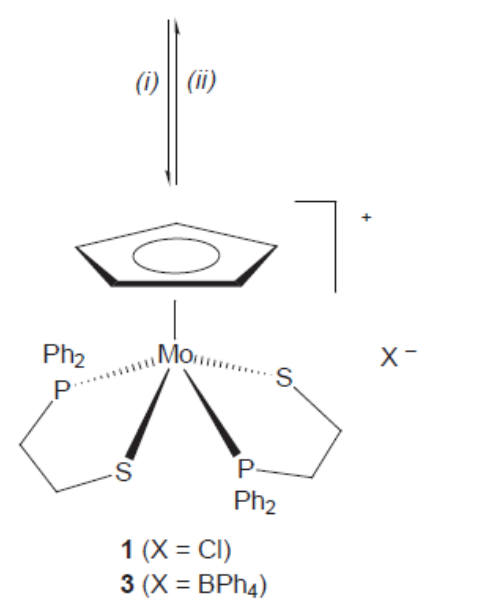

(equation 4)

The reversibility of the redox process in eq. 4 can also be witnessed by electrochemical investigations. The cyclic voltammogram of compound $\mathbf{4}$ shows a reversible oxidation wave at 
$E_{1 / 2}=-1.23 \mathrm{~V}$, which is quite close to the potential of the reversible reduction wave measured for compound $3\left(E_{1 / 2}=-1.25 \mathrm{~V}\right)$. This value is an indicator of the electron richness of this system relative to the $\mathrm{CpMoCl}_{2} \mathrm{~L}_{2}$ complexes ( $\mathrm{L}=$ tertiary phosphine), whose oxidation potentials are in the range $-0.33 \mathrm{~V}$ (for $\mathrm{L}_{2}=$ dppe) to $-0.63 \mathrm{~V}$ (for $\mathrm{L}=\operatorname{PPr}^{\mathrm{n}} 3$ ). ${ }^{14}$ This illustrates the greater donor capability of a thiolate ligand relative to a chloride. Since compound $\mathbf{3}$ is shown by the X-ray analysis to adopt a trans geometry, the reversibility of the redox process indicates the same relative configuration for compound $\mathbf{4}$, confirming the prediction previously made on the basis of the $a_{\mathrm{P}}$ value in the EPR spectrum.

A view of the cation of compound $\mathbf{3}$ is shown in Figure 1, and bond lengths and angles in Table 1. The geometry can be described as a four-legged piano stool, with the pairs of sulfur and phosphorus atoms occupying relative trans positions to yield an approximate $C_{2}$ local symmetry. The CNT-Mo-L angles (CNT = center of gravity of the Cp ring) are larger for the thiolate donors than for the phosphorus donors, as predicted on the basis of the $\pi$-donor/acceptor properties of these ligands and the diamagnetic configuration of the complex. ${ }^{25}$

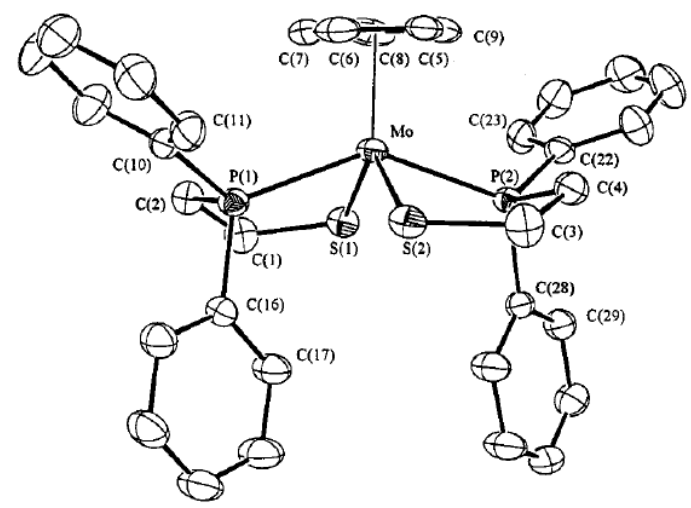

Figure 1. An ORTEP view of the cation of compound $\mathbf{3}$ with thermal ellipsoids drawn at the $30 \%$ probability level. Hydrogen atoms are omitted for clarity.

Table 1. Selected bond distances $(\AA)$ and angles $\left({ }^{\circ}\right)$ for compound $3{ }^{a}$

$\begin{array}{lccc}\text { Mo-CNT } & 1.98(2) & \text { Mo-S }(2) & 2.3134(9) \\ \text { Mo-S(1) } & 2.3261(9) & \text { Mo-P(1) } & 2.4770(9) \\ \text { Mo-P(2) } & 2.4824(9) & & \end{array}$

\begin{tabular}{lccr} 
CNT-Mo-S(1) & $125(1)$ & S(1)-Mo-P(1) & $77.84(3)$ \\
CNT-Mo-S(2) & $116(1)$ & S(1)-Mo-P(2) & $82.22(3)$ \\
CNT-Mo-P(1) & $111(1)$ & S(2)-Mo-P(1) & $82.72(3)$ \\
CNT-Mo-P(2) & $108(1)$ & $\mathrm{S}(2)-$ Mo-P(2) & $77.64(3)$ \\
S(1)-Mo-S(2) & $118.82(3)$ & $\mathrm{P}(1)-$ Mo-P(2) & $140.56(3)$ \\
\hline
\end{tabular}

${ }^{a} \mathrm{CNT}$ is the centroid of the cyclopentadienyl ring. 
The geometry and metric parameters can be best compared with those of the isoelectronic oxo compound $\mathrm{MoO}\left(\mathrm{SCH}_{2} \mathrm{CH}_{2} \mathrm{PPh}_{2}\right)_{2} \cdot{ }^{26}$ Both are compounds of $\mathrm{Mo}$ (IV) with the same bifunctional ligand, the $\mathrm{O}^{2-}$ and $\mathrm{Cp}^{-}$ligands being both capable of establishing three bonding interactions $(\sigma+2 \pi)$ and, therefore, being able to donate 6 electrons to the metal center. The Mo$\mathrm{P}$ distances are comparable in the two compounds, whereas the Mo-S distances are significantly shorter in the cation of 3 relative to the oxo analogue $\left(2.372(4) \AA\right.$ and $2.348(4) \AA$ ). ${ }^{26}$ This difference can be rationalized by the stronger electron donating capability of the $\mathrm{O}^{2-}$ ligand relative to the $\mathrm{Cp}^{-}$, as also indirectly established from other comparisons. ${ }^{27}$

\section{Reactions with the $\mathrm{Ph}_{2} \mathrm{PCH}_{2} \mathrm{CH}_{2} \mathrm{SCH}_{3}$ ligand.}

The reaction between $\mathrm{CpMoCl}_{2}$ and the phosphine-thioether ligand $\mathrm{Ph}_{2} \mathrm{PCH}_{2} \mathrm{CH}_{2} \mathrm{SCH}_{3}$ leads to the addition product $\mathbf{5}$, see Scheme 1, which was isolated as a microcrystalline red solid and characterized by elemental analysis, EPR spectroscopy, and cyclic voltammetry. The compound is indefinitely stable under an argon atmosphere at $-80^{\circ} \mathrm{C}$, but decomposes at room temperature rather quickly even under an inert atmosphere. The EPR spectrum shows the expected doublet due to coupling with a phosphorus atom $\left(g=1.973, a_{\mathrm{P}}=24.7 \mathrm{G}, a_{\mathrm{Mo}}=35.9\right.$ $\mathrm{G})$. These properties compare quite well with those of the diphosphine derivatives $\mathrm{CpMoCl}_{2}(\mathrm{~L}-$ L) (L-L = dppe, dmpe) for which a four-legged piano-stool structure with a cis arrangement of the two phosphorus donors was demostrated. ${ }^{12,28}$ An analogous structure is therefore proposed also for compound 5. In particular, the phosphorus hyperfine coupling constant of $\mathbf{5}$ is only slightly smaller than those of the diphosphine analogues ( $26 \mathrm{G}$ for the dppe complex and $28 \mathrm{G}$ for the dmpe complex) and the Mo hyperfine coupling constant is correspondingly slightly greater (29 and $33 \mathrm{G}$ for dppe and dmpe analogues, respectively). The alternative trans arrangement, observed for the bulkier $\mathrm{Cp}^{*} \mathrm{MoCl}_{2}$ (dppe) derivative, leads to completely different spectral parameters. ${ }^{23}$ The $g$ factor was shown to be highly dependent on the nature of the halide ligands but rather independent on the phosphine substituents (in the 1.978-1.994 range for the dichloride complexes). The g value recorded for compound $\mathbf{5}$ is at the low end of this range, and the direct comparison with the value for $\mathrm{CpMoCl}_{2}$ (dppe) $(g=1.986)^{12}$ indicates a rather small low-field shift caused by the replacement of a $\mathrm{PPh}_{2}$ donor with a $\mathrm{SMe}$ donor. Compound 5 shows a reversible oxidation wave at $E_{1 / 2}=0.12 \mathrm{~V}$ in the cyclic voltammogram. This is $0.45 \mathrm{~V}$ more positive relative to the oxidation process of the analogous $\mathrm{CpMoCl}_{2}$ (dppe) complex, ${ }^{14}$ indicating that the SMe group is a weaker electron donor relative to the $\mathrm{PPh}_{2}$ group, as expected from the different electronegativity of the two donor elements. 


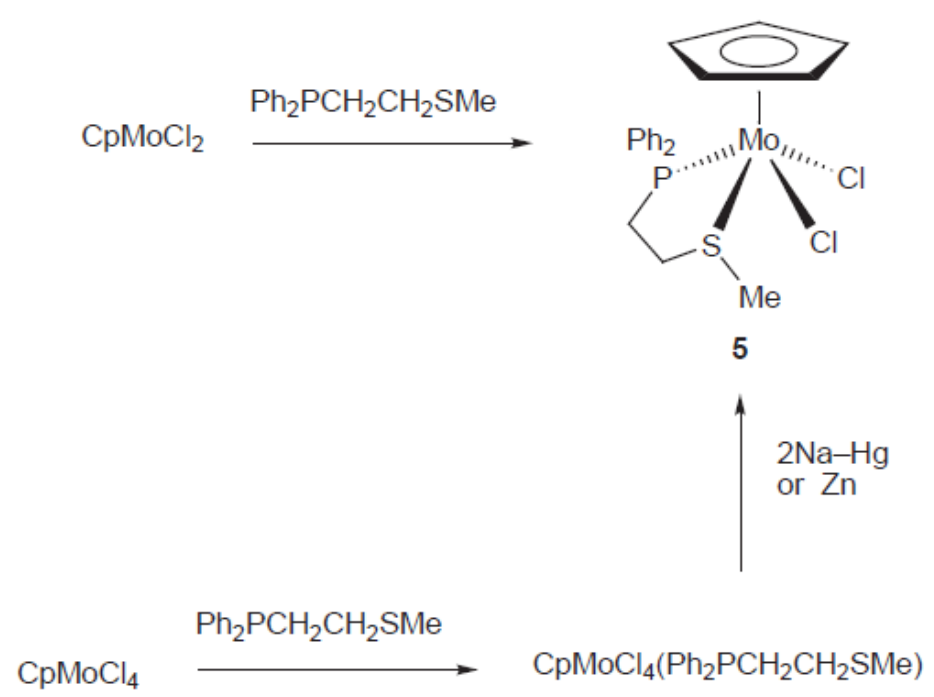

6

\section{Scheme 1}

Compound 5 has also been prepared by an alternative procedure (Scheme 1). The reaction between $\mathrm{CpMoCl}_{4}$ and one equivalent of the ligand in $\mathrm{CH}_{2} \mathrm{Cl}_{2}$ affords the corresponding addition product $\mathrm{CpMoCl}_{4}\left(\mathrm{Ph}_{2} \mathrm{PCH}_{2} \mathrm{CH}_{2} \mathrm{SCH}_{3}\right), \mathbf{6}$, in good yields. Reduction of compound $\mathbf{6}$ in THF with either two equivalents of sodium amalgam or one equivalent of $\mathrm{Zn}$ gives the Mo(III) complex 5. The EPR spectrum of compound $\mathbf{6}$ does not show coupling to the phosphorus atom (singlet at $g=1.954, a_{\mathrm{Mo}}=51.8 \mathrm{G}$ ). Previously reported phosphine adducts of alkyl-substituted cyclopentadienyl derivatives of $\mathrm{Mo}(\mathrm{V})$ display rather large phosphorus hyperfine constants (greater than $24 \mathrm{G}$ ), ${ }^{29-31}$ thus indicating the possibility that the bifunctional ligand binds the metal in a monodentate fashion via the sulfur donor in compound 6. However, we find that the addition of the electronically similar $\mathrm{PMePh}_{2}$ ligand to $\mathrm{CpMoCl}_{4}$ affords an EPR spectrum which consists of a single resonance with no observable hyperfine coupling to the P nucleus. The $g$ value and $a_{\mathrm{Mo}}$ hyperfine coupling of this spectrum are very similar to those of the $\mathrm{Ph}_{2} \mathrm{PCH}_{2} \mathrm{CH}_{2} \mathrm{SMe}$ adduct (see Experimental section). Therefore, phosphorus coordination to the metal center remains a structural possibility. We have also considered the possibility of a bidentate coordination mode for the phosphine-thioether ligand. This alternative arrangement would likely induce the displacement of a chloro ligand, to afford an ionic isomer, $\left[\mathrm{CpMoCl}_{3}\left(\eta^{2}-\mathrm{Ph}_{2} \mathrm{PCH}_{2} \mathrm{CH}_{2} \mathrm{SMe}-P, S\right)\right]^{+} \mathrm{Cl}^{-}$. Electrical conductivity measurements indicate the presence of ionic species $\left(\Lambda_{\infty}=9.3\right.$ and $90.5 \mathrm{~S} \mathrm{~cm}^{2} \mathrm{~mol}^{-1}$ in THF and MeCN solutions, respectively). The values measured, however, are slightly smaller than those typically observed for fully dissociated 1:1 salts. ${ }^{32}$ A possible rationalization of this result is the existence of an equilibrium between ionic and neutral isomeric forms. 
An attempt was made to methylate compound $\mathbf{5}$ with methyllithium. The reaction with one equivalent of $\mathrm{MeLi}$ carried out at $-80^{\circ} \mathrm{C}$ in THF led to the disappearance of the starting material without the appearance of new EPR-active species. The ${ }^{31} \mathrm{P}\left\{{ }^{1} \mathrm{H}\right\}$ NMR spectrum showed the formation of a complex mixture of several products, which was not further investigated. When two equivalents of MeLi were used, the immediately recorded EPR spectrum showed a new doublet resonance $\left(g=1.987, a_{\mathrm{P}}=24.3 \mathrm{G}, a_{\mathrm{Mo}}=38.6 \mathrm{G}\right)$, which we tentatively assign to the dimethyl product $\mathrm{CpMo}\left(\mathrm{CH}_{3}\right)_{2}\left(\mathrm{Ph}_{2} \mathrm{PCH}_{2} \mathrm{CH}_{2} \mathrm{SMe}\right)$, but the signal disappeared after ca. $1 / 2 \mathrm{~h}$ at room temperature. The ${ }^{31} \mathrm{P}\left\{{ }^{1} \mathrm{H}\right\}$ NMR spectrum showed the release of the free ligand $\mathrm{Ph}_{2} \mathrm{PCH}_{2} \mathrm{CH}_{2} \mathrm{SMe}$. An analogous alkylation attempts had been carried out previously for compound $\mathrm{CpMoCl}_{2}\left(\mathrm{PMe}_{3}\right)_{2}$, also resulting in decomposition of the alkylation product, ${ }^{13}$ whereas the alkylation of $\mathrm{CpMoCl}_{2}\left(\eta^{4}-\mathrm{C}_{4} \mathrm{H}_{6}\right)$ affords thermally stable dialkyl derivatives. ${ }^{33}$ The positive shift of the $g$ value upon methylation of compound 5 (from 1.973 to 1.987) parallels those observed upon methylation of $\mathrm{CpMoCl}_{2}\left(\mathrm{PMe}_{3}\right)_{2}$ (from 1.982 to 2.003) and $\mathrm{CpMoCl}_{2}\left(\eta^{4}-\mathrm{C}_{4} \mathrm{H}_{6}\right.$ ) (from 1.994 to 2.012).

\section{Discussion}

The addition of neutral ligands to $\mathrm{CpMoCl}_{2}$ to form 17-electron $\mathrm{CpMoCl}_{2} \mathrm{~L}_{2}$ adducts had previously been established when $\mathrm{L}=$ tertiary phosphine ${ }^{11,14}$ or $\mathrm{L}_{2}=$ diphosphine $^{12}$ and diene. ${ }^{34}$ In this contribution, we have analyzed the results of the addition of the bifunctional ligands $\mathrm{Ph}_{2} \mathrm{PCH}_{2} \mathrm{CH}_{2} \mathrm{SR}\left(\mathrm{R}=\mathrm{H}, \mathrm{CH}_{3}\right)$. An isolable addition product (compound 5) is only obtained for $\mathrm{R}=\mathrm{CH}_{3}$. When $\mathrm{R}=\mathrm{H}$, the addition intermediate (which can be spectroscopically observed) rapidly evolves to lead to the isolation of two different products, $\mathbf{1}$ and $\mathbf{2}$, in a relative ratio that depends on the amount of ligand used. The results of the electrochemical investigations help us formulate a mechanism for the formation of these compounds (see Scheme 2). 


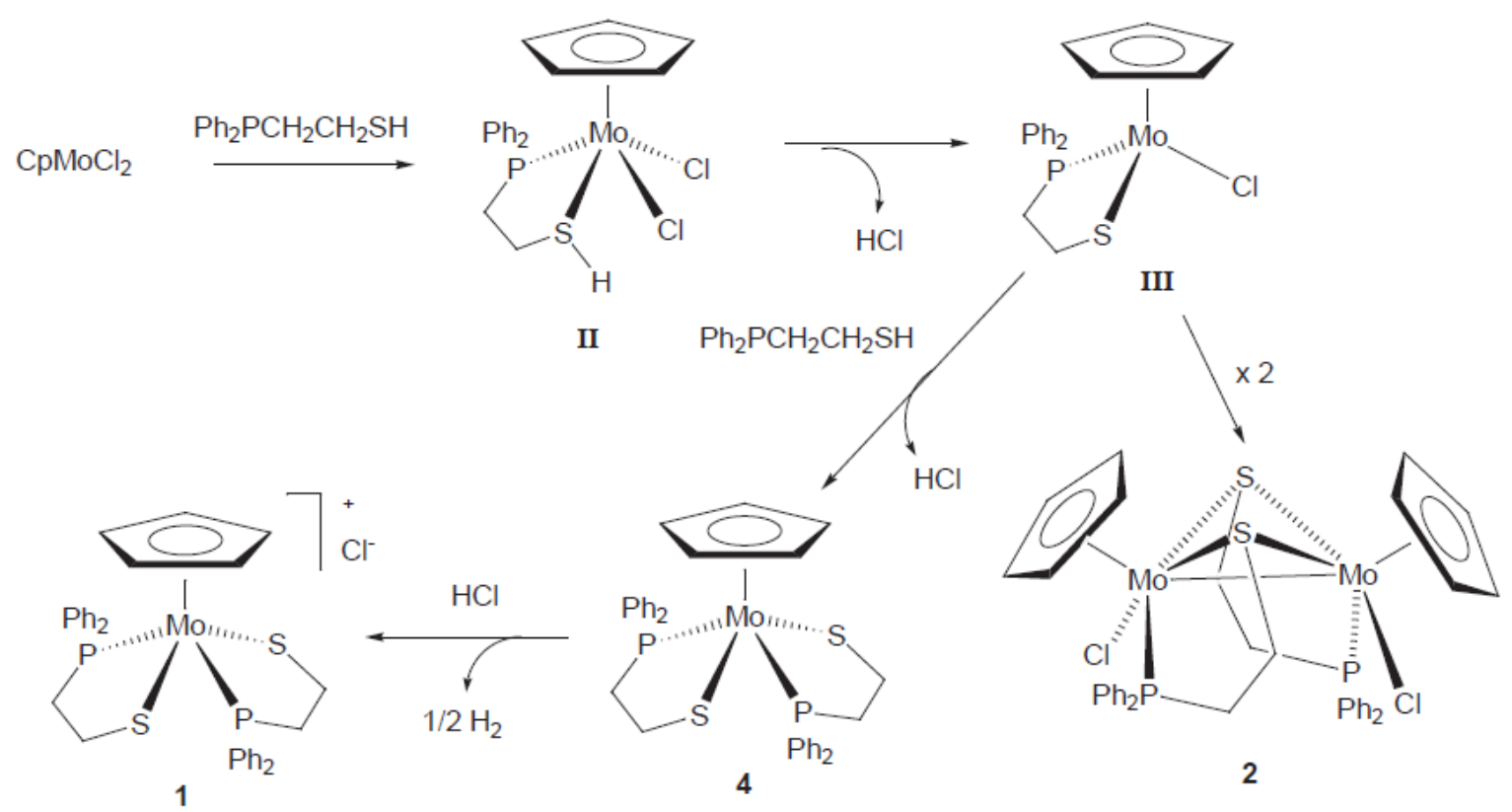

Scheme 2

The difference between the two addition products is likely due to the acidity of the SH function, especially once this is coordinated to the metal center. Thus, deprotonation of the intermediate II and loss of chloride would lead to the unsaturated complex III. A related deprotonation process has been described for a very similar reaction, namely the addition of $\mathrm{HS}\left(\mathrm{CH}_{2}\right)_{n} \mathrm{SH}(\mathrm{n}=2,3)$ to $\mathrm{Cp}_{2} \mathrm{Mo}_{2}(\mu-\mathrm{SMe})_{3}(\mu-\mathrm{Cl})$, whereby the dinuclear product $\mathrm{Cp}_{2} \mathrm{Mo}_{2}(\mu-$ $\mathrm{SMe})_{3}\left[\mu-\mathrm{S}\left(\mathrm{CH}_{2}\right)_{n} \mathrm{SH}\right]$ is obtained with elimination of $\mathrm{HCl}^{35}$ Compound $\mathrm{CpMoCl}_{2}$ is also a dinuclear compound with four bridging chloro ligands. ${ }^{36-38}$ Intermediate III can evolve to a saturated product either by dimerization, leading directly to the observed product $\mathbf{2}$, or by addition of a second molecule of the ligand $\mathrm{Ph}_{2} \mathrm{PCH}_{2} \mathrm{CH}_{2} \mathrm{SH}$. Further deprotonation and chloride loss would afford compound 4 , but the redox properties of this 17-electron Mo(III) product make it susceptible to oxidation by the available protons, as it has independently been verified, to afford the observed Mo(IV) product 1 . The essential features of this proposed mechanism are consistent with the observation that the use of an increased amount of the ligand $\mathrm{Ph}_{2} \mathrm{PCH}_{2} \mathrm{CH}_{2} \mathrm{SH}$ increases the yield of $\mathbf{1}$ and decreases the yield of $\mathbf{2}$. In addition, compound $\mathbf{2}$ converts into compound 4 upon treatment with $\mathrm{Ph}_{2} \mathrm{PCH}_{2} \mathrm{CH}_{2} \mathrm{~S}^{-}$.

It is notable to observe that intermediate II has the same electronic configuration as compound 4, but is not oxidized under the reaction conditions that lead to products $\mathbf{1}$ and $\mathbf{2}$. The electrochemical investigation of the analogous thioether complex $\mathbf{5}$ indicates that the potential at which its oxidation would occur is much more positive relative to that of compound 4 (ca. $1.3 \mathrm{~V}$ more positive), revealing a dramatic effect of the ligands nature on the redox 
properties in this system. A comparison of the redox potentials for the $\mathrm{Mo}(\mathrm{III}) / \mathrm{Mo}(\mathrm{IV})$ processes in compounds $\mathbf{3 / 4}$ and $\mathbf{5}$ with that already reported in the literature for compound $\mathrm{CpMoCl}_{2}$ (dppe) (-0.33 V) shows trends in ligand donor properties in the order $\mathrm{RS}^{-}>\mathrm{Cl}^{-}$and $\mathrm{RSMe}<\mathrm{RPPh}_{2}$. Both these two effects contribute to render compound 4 much more easily oxidized relative to compound $\mathbf{5}$.

\section{Conclusions}

The present study is relevant in comparison with previous investigations of electron-poorer half-sandwich Mo(III) complexes, which by and large prefer to adopt a dinuclear structure with a metal-metal bond. The combination of a sulfur ligand (alkylsulfido or thioether) with a phosphorus donor in a chelating bifunctional ligand leads to stable mononuclear, electron-richer compounds. This greater electron-richness is clearly manifested in the oxidation of Mo(III) to Mo(IV) by the protons generated from coordinated mercaptans, to yield $\mathrm{H}_{2}$. Similar oxidation of dinuclear, thiolate-bridged cyclopentadienyl derivatives of Mo(III) by the proton have been reported. ${ }^{7}$

\section{Experimental}

All reactions were carried out in dry solvents under a dinitrogen or argon atmosphere by the use of Schlenk line or glove-box techniques. The solvents were dried by conventional methods $\left(\mathrm{CH}_{2} \mathrm{Cl}_{2}\right.$ from $\mathrm{CaH}_{2}$, THF from $\mathrm{Na} / \mathrm{K}$, pentane and toluene from $\mathrm{Na}$ /benzophenone) and distilled under nitrogen prior to use. Deuterated solvents were dried over molecular sieves and degassed by 3 freeze-pump-thaw cycles prior to use. ${ }^{1} \mathrm{H}$ and ${ }^{31} \mathrm{P}\left\{{ }^{1} \mathrm{H}\right\}$-NMR measurements were carried out on a Bruker AC200 spectrometer. The peak positions are reported with positive shifts downfield of TMS as calculated from the residual solvent peaks $\left({ }^{1} \mathrm{H}\right)$ or downfield of external $85 \% \mathrm{H}_{3} \mathrm{PO}_{4}\left({ }^{31} \mathrm{P}\right)$. EPR measurements were carried out at the $\mathrm{X}$-band microwave frequency on a Bruker ESP300 spectrometer. The spectrometer frequency was calibrated with DPPH $(g=2.0037)$. Cyclic voltammograms were carried out at room temperature with a Radiometer digital electrochemical analyzer (model DEA332). The electrochemical cell was fitted with an SCE reference electrode, a platinum disk working electrode and a Pt wire counterelectrode. $\mathrm{Bu}_{4} \mathrm{NPF}_{6}$ (ca $0.1 \mathrm{M}$ ) was used as supporting electrolyte. All potentials are reported relative to the ferrocene standard, which was added to each solution and measured at 
the end of the experiments. The solution conductivity measurements were carried out at $25^{\circ} \mathrm{C}$ with a Tacussel type CD6 N conductimeter equipped with an XE 110 cell which had been calibrated with a $0.1 \mathrm{M} \mathrm{KCl}$ solution. The elemental analyses were carried out by the analytical service of the Laboratoire de Synthèse et d'Electrosynthèse Organométalliques. $\mathrm{NaBPh}_{4}$, $\mathrm{HBF}_{4} \cdot \mathrm{OEt}_{2}, \mathrm{MeLi}\left(1 \mathrm{M}\right.$ solution in diethyl ether), $\mathrm{Bu}{ }^{\mathrm{n}} \mathrm{Li}$ (1.6 M solution in hexanes), Bu ${ }^{\mathrm{t}} \mathrm{OK}$ and $\mathrm{Zn}$ powder were used as received, without further purification. $\mathrm{CpMoCl} 4,{ }^{39} \mathrm{CpMoCl}_{2},{ }^{40}$ $\mathrm{Ph}_{2} \mathrm{PCH}_{2} \mathrm{CH}_{2} \mathrm{SH},{ }^{26}$ and $\left[\mathrm{Cp}_{2} \mathrm{Fe}\right] \mathrm{BF}_{4},{ }^{41}$ were prepared according to literature procedures. $\mathrm{Ph}_{2} \mathrm{PCH}_{2} \mathrm{CH}_{2} \mathrm{SCH}_{3}$ was prepared by a slight modification of the method described in the literature: ${ }^{42}$ to a solution of $\mathrm{Ph}_{2} \mathrm{PCH}_{2} \mathrm{CH}_{2} \mathrm{SH}(1.057 \mathrm{~mL}, 4.57 \mathrm{mmol})$ in $20 \mathrm{~mL}$ of $\mathrm{THF}$ at $0^{\circ} \mathrm{C}$ was added a solution of $1.6 \mathrm{M} \mathrm{Bu} \mathrm{Li}(2.85 \mathrm{~mL}, 4.57 \mathrm{mmol})$ and $\mathrm{MeI}(284 \mathrm{ml}, 4.57 \mathrm{mmol})$. The mixture was stirred overnight. The solvent was evaporated in vacuo, the residue was extracted with pentane, filtered through Celite, and concentrated in vacuo to ca. $20 \mathrm{~mL}$. Cooling to $-80^{\circ} \mathrm{C}$ for $24 \mathrm{~h}$ afforded white crystals of $\mathrm{Ph}_{2} \mathrm{PCH}_{2} \mathrm{CH}_{2} \mathrm{SCH}_{3}$. The ${ }^{1} \mathrm{H}$ and ${ }^{31} \mathrm{P}$ NMR properties of this product are identical with those previously reported. ${ }^{42}$ Yield: $0.845 \mathrm{~g}, 71 \%$.

\section{Synthesis of $\left[\mathrm{CpMo}\left(\mathrm{SCH}_{2} \mathrm{CH}_{2} \mathrm{PPh}_{2}\right)_{2}\right] \mathrm{Cl}$ (1)}

A solution of $\mathrm{Ph}_{2} \mathrm{PCH}_{2} \mathrm{CH}_{2} \mathrm{SH}\left(474 \mathrm{~mL}, 2.17 \mathrm{mmol}\right.$ ) in $5 \mathrm{~mL}$ of $\mathrm{CH}_{2} \mathrm{Cl}_{2}$ was added to a suspension of $\mathrm{CpMoCl}_{2}(0.143 \mathrm{~g}, 0.62 \mathrm{mmol})$ in $10 \mathrm{~mL}$ of $\mathrm{CH}_{2} \mathrm{Cl}_{2}$ and the mixture was stirred overnight at room temperature. An immediate analysis of the supernatant solution by EPR spectroscopy revealed a doublet resonance $\left(a_{\mathrm{P}}=26.20 \mathrm{G}\right)$ at $g=1.982$. After a few minutes this EPR signal was no longer present. Compound 1 precipitated as a very insoluble yellow solid, which was collected on a filter, washed with $\mathrm{CH}_{2} \mathrm{Cl}_{2}(4 \times 5 \mathrm{~mL})$ and dried in vacuo. Yield: 0.244 g, 57\%. Anal. Calcd for $\mathrm{C}_{33} \mathrm{H}_{33} \mathrm{ClMoP}_{2} \mathrm{~S}_{2}$ : C, 57.69; H, 4.84; S, 9.33. Found C, 57.27; H, 4.87; $\mathrm{S}$, 8.96. ${ }^{31} \mathrm{P}\left\{{ }^{1} \mathrm{H}\right\}-\mathrm{NMR}\left(\mathrm{CH}_{3} \mathrm{OH}\right.$, with external $\mathrm{D}_{2} \mathrm{O}$ capillary): $85.1 \mathrm{ppm}$.

\section{Synthesis of $\left[\mathrm{CpMoCl}\left(\mathrm{SCH}_{2} \mathrm{CH}_{2} \mathrm{PPh}_{2}\right)\right]_{2}(2)$}

A solution of $\mathrm{Ph}_{2} \mathrm{PCH}_{2} \mathrm{CH}_{2} \mathrm{SH}(628 \mathrm{~mL}, 2.88 \mathrm{mmol})$ in $5 \mathrm{~mL}$ of $\mathrm{CH}_{2} \mathrm{Cl}_{2}$ was added to a suspension of $\mathrm{CpMoCl}_{2}(0.668 \mathrm{~g}, 2.88 \mathrm{mmol})$ in $20 \mathrm{~mL}$ of $\mathrm{CH}_{2} \mathrm{Cl}_{2}$ and the mixture was stirred overnight at room temperature. A yellow microcrystalline precipitate corresponding to compound 1 which had formed was filtered (yield: $0.402 \mathrm{~g}, 20 \%$ ). The solution filtered again through Celite, concentrated in vacuo ca. $5 \mathrm{~mL}$, layered with pentane $(20 \mathrm{~mL})$ and kept in a refrigerator at $-20^{\circ} \mathrm{C}$ for several days. When the diffusion was complete compound 2 was obtained as a microcrystalline brown solid. Yield: $0.589 \mathrm{~g}, 46 \%$. Anal. Calcd for $\mathrm{C}_{19} \mathrm{H}_{19} \mathrm{ClMoPS}$ : C, 51.66; H, 4.33; S, 7.26. Found C, 51.28; H, 4.69; S, 6.97. ${ }^{31} \mathrm{P}\left\{{ }^{1} \mathrm{H}\right\}-\mathrm{NMR}$ 
$\left(\mathrm{CDCl}_{3}, \delta\right): 78.5$ ppm. ${ }^{1} \mathrm{H}-\mathrm{NMR}\left(\mathrm{CDCl}_{3}, \delta\right): 7.88-7.32(\mathrm{~m}, 10 \mathrm{H}, \mathrm{Ph}), 4.92\left(\mathrm{~d}, J_{\mathrm{P}-\mathrm{H}}=2.20 \mathrm{~Hz}\right.$, 5H, Cp), 4.08-3.07 (m, 4H, $\left.\mathrm{SCH}_{2} \mathrm{CH}_{2} \mathrm{P}\right)$.

\section{Synthesis of $\left[\mathrm{CpMo}\left(\mathrm{SCH}_{2} \mathrm{CH}_{2} \mathrm{PPh}_{2}\right)_{2}\right] \mathrm{BPh}_{4}(3)$}

To a suspension of $\left[\mathrm{CpMo}\left(\mathrm{SCH}_{2} \mathrm{CH}_{2} \mathrm{PPh}_{2}\right)_{2}\right] \mathrm{Cl}(0.034 \mathrm{~g}, 0.05 \mathrm{mmol})$ in $10 \mathrm{~mL}$ of $\mathrm{THF}$ was added $\mathrm{NaBPh}_{4}(0.016 \mathrm{~g}, 0.05 \mathrm{mmol})$ and the mixture was stirred overnight at room temperature, resulting in the solubilization of the yellow starting material to yield an orange solution. After evaporation, the residue was redissolved in $10 \mathrm{~mL}$ of $\mathrm{CH}_{2} \mathrm{Cl}_{2}$. The resulting orange solution was filtered through Celite and concentrated under reduced pressure to ca. $5 \mathrm{~mL}$. Slow diffusion of pentane into this solution at $-20^{\circ} \mathrm{C}$ produced orange crystals after 3 days. Yield: $0.038 \mathrm{~g}$, $80 \%$. A suitable crystal obtained in this way was used for the X-ray analysis. Anal. Calcd for $\mathrm{C}_{57} \mathrm{H}_{53} \mathrm{BMoP}_{2} \mathrm{~S}_{2}$ : C, 70.52; H, 5.50; S, 6.60. Found C, 70.37; H, 5.40; S, 6.31. ${ }^{31} \mathrm{P}\left\{{ }^{1} \mathrm{H}\right\}-\mathrm{NMR}$ $\left(\mathrm{CD}_{2} \mathrm{Cl}_{2}, \delta\right): 83.4$ ppm. ${ }^{1} \mathrm{H}-\mathrm{NMR}\left(\mathrm{CD}_{2} \mathrm{Cl}_{2}, \delta\right): 7.48-6.79$ (m, 40H, Ph), $4.40\left(\mathrm{t}, J_{\mathrm{P}-\mathrm{H}}=1.83 \mathrm{~Hz}\right.$, $5 \mathrm{H}, \mathrm{Cp}), 3.68-2.90\left(\mathrm{~m}, 8 \mathrm{H}, \mathrm{SCH}_{2} \mathrm{CH}_{2} \mathrm{P}\right)$. Cyclic Voltammetry (THF, room temperature): reversible reduction at $E_{1 / 2}=-1.25 \mathrm{~V}$.

\section{Synthesis of $\mathrm{CpMo}\left(\mathrm{SCH}_{2} \mathrm{CH}_{2} \mathrm{PPh}_{2}\right)_{2}(4)$}

A) From CpMoCl 2 and two equiv of $\mathrm{Ph}_{2} \mathrm{PCH}_{2} \mathrm{CH}_{2} \mathrm{~S}^{-} \mathrm{Li}^{+}$. A solution of $\mathrm{Ph}_{2} \mathrm{PCH}_{2} \mathrm{CH}_{2} \mathrm{~S}^{-} \mathrm{Li}^{+}$, prepared in situ from $\mathrm{Ph}_{2} \mathrm{PCH}_{2} \mathrm{CH}_{2} \mathrm{SH}$ (496 mL, $2.15 \mathrm{mmol}$ ) and MeLi (2.15 mL, $2.15 \mathrm{mmol}$ ) in $10 \mathrm{~mL}$ of THF, was added to a suspension of $\mathrm{CpMoCl}_{2}(0.255 \mathrm{~g}, 1.07 \mathrm{mmol})$ in $40 \mathrm{~mL}$ of THF. The mixture was stirred overnight at room temperature. The brown-red solution was evaporated under reduced pressure. The residue was extracted in toluene and filtered through Celite. The solvent was evaporated in vacuo, the residue was washed with cold pentane $(3 \mathrm{x}$ $5 \mathrm{~mL}$ ) and dried under vacuum. Yield: $0.382 \mathrm{~g}, 55 \%$. EPR (hexane): $g=1.987$ (triplet with Mo satellites, $\left.a_{\mathrm{P}}=3.94 \mathrm{G}, a_{\mathrm{Mo}}=32.39 \mathrm{G}\right)$. Cyclic voltammetry (THF, room temperature): reversible oxidation at $E_{1 / 2}=-1.23 \mathrm{~V}$.

B) By reduction of compound 1. By MeLi. To a suspension of compound $1(0.091 \mathrm{~g}, 0.132$ $\mathrm{mmol})$ in $20 \mathrm{~mL}$ of toluene was added dropwise $264 \mathrm{ml}$ (0.264 mmol) of a MeLi solution (1 M in diethyl ether) causing the dissolution of the yellow starting material within $30 \mathrm{~min}$ and formation of a brown-red solution. The solution was evaporated under reduced pressure to ca. $10 \mathrm{~mL}$ and filtered through Celite. The solvent was further evaporated until dryness and the residue was washed with cold pentane $(3 \times 5 \mathrm{~mL})$ and dried under reduced pressure. Yield: $0.060 \mathrm{~g}, 69.83 \%$. This product had spectroscopic (EPR) and electrochemical properties identical those of the material obtained by method A. 
By ButOK. To a suspension of compound $1(0.084 \mathrm{~g}, 0.122 \mathrm{mmol})$ in $20 \mathrm{~mL}$ of THF was added $\mathrm{Bu}^{\mathrm{t} O K}(0.027 \mathrm{~g}, 0.244 \mathrm{mmol})$. After $24 \mathrm{~h}$ of stirring at room temperature the solvent was removed in vacuo. The residue was extracted with toluene and filtered through Celite, the solution was evaporated to dryness under reduced pressure and the residue was washed with cold pentane $(3 \times 5 \mathrm{~mL})$ and dried under vacuum. Yield: $0.185 \mathrm{~g}, 72.88 \%$. Anal. Calcd for $\mathrm{C}_{33} \mathrm{H}_{33} \mathrm{MoP}_{2} \mathrm{~S}_{2}$ : C, 60.83; H, 5.10; S, 9.84. Found C, 61.15; H, 5.36; S, 9.31.

C) By reduction of compound 3. To a solution of $\left[\mathrm{CpMo}\left(\mathrm{SCH}_{2} \mathrm{CH}_{2} \mathrm{PPh}_{2}\right)_{2}\right] \mathrm{BPh}_{4}(0.010 \mathrm{~g}$, $0.01 \mathrm{mmol})$ in $2 \mathrm{~mL}$ of THF was added $\mathrm{Na}(0.023 \mathrm{~g}, 0.01 \mathrm{mmol})$ and the mixture was stirred at room temperature for $45 \mathrm{~min}$. During this time, the yellow solution became red and the EPR spectrum showed the signal corresponding to compound 4. The EPR properties matched those described above for the product of method A.

D) From compound 2 and two equiv of $\mathrm{Ph}_{2} \mathrm{PCH}_{2} \mathrm{CH}_{2} \mathrm{~S}^{-} \mathrm{Li}^{+}$. To a solution of compound 2 (0.007 g, $0.009 \mathrm{mmol})$ in $1 \mathrm{~mL}$ of THF was added a solution of $\mathrm{Ph}_{2} \mathrm{PCH}_{2} \mathrm{CH}_{2} \mathrm{~S}^{-} \mathrm{Li}^{+}$, prepared in situ from $\mathrm{Ph}_{2} \mathrm{PCH}_{2} \mathrm{CH}_{2} \mathrm{SH}(5 \mathrm{~mL}, 0.018 \mathrm{mmol})$ and MeLi $(18 \mathrm{~mL}, 0.018 \mathrm{mmol})$ in $1 \mathrm{~mL}$ of THF. The brown solution became red. The EPR spectrum shows the signal corresponding to compound 4.

\section{NMR study of the chemical oxidation of compound 4}

A) By ferrocenium. To a solution of compound $4(0.006 \mathrm{~g}, 0.01 \mathrm{mmol})$ in $5 \mathrm{~mL}$ of THF was added $\left[\mathrm{Cp}_{2} \mathrm{Fe}\right] \mathrm{BF}_{4}(0.027 \mathrm{~g}, 0.01 \mathrm{mmol})$ and the mixture was stirred for $15 \mathrm{~min}$. The red solution changes to yellow and it becomes EPR silent. The ${ }^{31} \mathrm{P}\left\{{ }^{1} \mathrm{H}\right\}$-NMR (THF) shows one sharp peak at $84.7 \mathrm{ppm}$ attributed to $\left[\mathrm{CpMo}\left(\mathrm{SCH}_{2} \mathrm{CH}_{2} \mathrm{PPh}_{2}\right)_{2}\right] \mathrm{BF}_{4}$.

B) By HBF4. To a solution of compound 4 (41.65 g, $0.064 \mathrm{mmol})$ in $1 \mathrm{~mL}$ of $\mathrm{C}_{6} \mathrm{D}_{6}$ was added $\mathrm{HBF}_{4} \cdot \mathrm{OEt}_{2}(0.064 \mathrm{mmol}, 69 \mathrm{~mL})$ at $0^{\circ} \mathrm{C}$. Gas evolution was immediately observed, discharging the red colour of the solution and yielding a yellow precipitate. ${ }^{1} \mathrm{H}-\mathrm{NMR}\left(\mathrm{C}_{6} \mathrm{D}_{6}, \delta\right): 4.50\left(\mathrm{~s}, \mathrm{H}_{2}\right)$. The suspension was filtered and the yellow solid was dissolved in THF. ${ }^{31} \mathrm{P}\left\{{ }^{1} \mathrm{H}\right\}-\mathrm{NMR}$ (THF, $\delta): 84.7 \mathrm{ppm}$.

\section{Synthesis of $\mathrm{CpMoCl}_{2}\left(\mathrm{CH}_{3} \mathrm{SCH}_{2} \mathrm{CH}_{2} \mathrm{PPh}_{2}\right)$ (5) from $\mathrm{CpMoCl}_{2}$ and $\mathrm{Ph}_{2} \mathrm{PCH}_{2} \mathrm{CH}_{2} \mathrm{SCH}_{3}$}

To a suspension of $\mathrm{CpMoCl}_{2}(0.185 \mathrm{~g}, 0.8 \mathrm{mmol})$ in $15 \mathrm{~mL}$ of $\mathrm{CH}_{2} \mathrm{Cl}_{2}$ was added a solution of $\mathrm{Ph}_{2} \mathrm{PCH}_{2} \mathrm{CH}_{2} \mathrm{SCH}_{3}(0.209 \mathrm{~g}, 0.8 \mathrm{mmol})$ in $5 \mathrm{~mL}$ of $\mathrm{CH}_{2} \mathrm{Cl}_{2}$ at room temperature. The mixture was stirred for $2 \mathrm{~h}$, filtered through Celite and concentrated under reduced pressure to ca. $5 \mathrm{~mL}$. Addition of pentane (20 mL) gave 6 as a brown-red microcrystalline solid. Yield: $0.324 \mathrm{~g}, 82 \%$. 
Anal. Calcd for $\mathrm{C}_{20} \mathrm{H}_{22} \mathrm{Cl}_{2}$ MoPS: C, 48.80; H, 4.50; S, 6.51. Found C, 48.76; H, 4.87; S, 5.91. EPR (hexane): $g=1.973$ (doublet, with Mo satellites, $a_{\mathrm{P}}=24.7 \mathrm{G}, a_{\mathrm{Mo}}=35.9 \mathrm{G}$ ). Cyclic voltammetry $\left(\mathrm{CH}_{2} \mathrm{Cl}_{2}\right.$, room temperature): reversible oxidation at $E_{1 / 2}=0.12 \mathrm{~V}$.

\section{Synthesis of $\mathrm{CpMoCl}_{4}\left(\mathrm{CH}_{3} \mathrm{SCH}_{2} \mathrm{CH}_{2} \mathrm{PPh}_{2}\right)(6)$}

A solution of $\mathrm{Ph}_{2} \mathrm{PCH}_{2} \mathrm{CH}_{2} \mathrm{SCH}_{3}(0.551 \mathrm{~g}, 2.11 \mathrm{mmol})$ in $5 \mathrm{~mL}$ of $\mathrm{CH}_{2} \mathrm{Cl}_{2}$ was added to a suspension of $\mathrm{CpMoCl}_{4}(0.669 \mathrm{~g}, 2.21 \mathrm{mmol})$ in $20 \mathrm{~mL}$ of $\mathrm{CH}_{2} \mathrm{Cl}_{2}$ at $-80^{\circ} \mathrm{C}$. The solution was warmed to room temperature, stirred for $3 \mathrm{~h}$ and filtered through Celite. The filtrate was concentrated under reduced pressure to ca. $5 \mathrm{~mL}$. Addition of pentane $(20 \mathrm{~mL})$ gave 6 as a brown-red microcrystalline solid. Yield: $1.152 \mathrm{~g}$, 96\%. Anal. Calcd for $\mathrm{C}_{20} \mathrm{H}_{22} \mathrm{Cl}_{4} \mathrm{MoPS}$ : C, 42.65; H, 3.94; S, 5.69. Found C, 42.28; H, 3.82; S, 5.65. EPR $\left(\mathrm{CH}_{2} \mathrm{Cl}_{2}\right): g=1.987$ (s, with Mo satellites, $\left.a_{\mathrm{Mo}}=51.82 \mathrm{G}\right)$. Molar conductivity $\left(\Lambda, \mathrm{S} \mathrm{cm}^{2} \mathrm{~mol}^{-1}\right)$; in THF: $2.6\left(8.9 \times 10^{-3} \mathrm{M}\right), 7.2$ $\left(8.9 \times 10^{-4} \mathrm{M}\right), \Lambda_{\infty}=9.3 \mathrm{~S} \mathrm{~cm}^{2} \mathrm{~mol}^{-1}$; in $\mathrm{MeCN}: 48.9\left(9.05 \times 10^{-3} \mathrm{M}\right), 75.7\left(9.05 \times 10^{-4} \mathrm{M}\right), \Lambda_{\infty}=$ $90.5 \mathrm{~S} \mathrm{~cm}^{2} \mathrm{~mol}^{-1}$.

\section{Reduction of compound 6 to compound 5}

A) By sodium amalgam. Compound $6(0.400 \mathrm{~g}, 0.71 \mathrm{mmol})$ was dissolved in THF $(20 \mathrm{~mL})$ and the solution was cooled to $0^{\circ} \mathrm{C}$. Freshly prepared sodium amalgam $(1 \% \mathrm{ww}, 0.032 \mathrm{~g}, 1.42$ mmol) was added and the mixture was stirred for $45 \mathrm{~min}$. The mixture was decanted and the solution was filtered (via cannula). The solvent was removed in vacuo and the solid residue was extracted with $\mathrm{CH}_{2} \mathrm{Cl}_{2}$ and filtered through Celite. The solution was evaporated and the precipitate was washed with pentane and dried under vacuum. Yield: $0.162 \mathrm{~g}, 46 \%$. This product had spectroscopic (EPR) properties identical those of the material obtained from $\mathrm{CpMoCl}_{2}$ and $\mathrm{Ph}_{2} \mathrm{PCH}_{2} \mathrm{CH}_{2} \mathrm{SMe}$ as described above.

B). By Zn. To a solution of compound $6(0.010 \mathrm{~g}, 0.017 \mathrm{mmol})$ in $5 \mathrm{~mL}$ of THF was cooled to $0^{\circ} \mathrm{C}$ and then $\mathrm{Zn}$ powder $(0.001 \mathrm{~g}, 0.025 \mathrm{mmol})$ was added. The mixture was stirred for $3 \mathrm{~h}$. An EPR investigation of this solution showed an identical spectrum as observed for the compound 5 as obtained by the two methods described above.

\section{Reactions of compound 5 with MeLi}

A) With one equivalent. A solution of compound $5(0.030 \mathrm{~g}, 0.11 \mathrm{mmol})$ in $10 \mathrm{~mL}$ of THF was cooled to $-80^{\circ} \mathrm{C}$ and then a solution of $\mathrm{MeLi}(109 \mathrm{~mL}, 0.109 \mathrm{mmol})$ was added dropwise via a microsyringe. The EPR spectrum showed a decrease in intensity of the EPR signal of the starting material until $\mathbf{5}$ was completely consumed, but no EPR-active products were observed. 
B) With two equivalents. To a cooled $\left(-80^{\circ} \mathrm{C}\right)$ solution of compound $5(0.046 \mathrm{~g}, 0.16 \mathrm{mmol})$ in $10 \mathrm{~mL}$ of THF was added dropwise a solution of MeLi $(320 \mathrm{~mL}, 0.32 \mathrm{mmol})$. The EPR spectrum recorded immediately showed a new doublet resonance with Mo satellites, $g=1.987$, $a_{\mathrm{P}}=24.3 \mathrm{G}, a_{\mathrm{Mo}}=38.6 \mathrm{G}$.

\section{Reaction between $\mathrm{CpMoCl}_{4}$ and $\mathrm{Ph}_{2} \mathrm{PMe}$.}

To a suspension of $\mathrm{CpMoCl}_{4}(0.028 \mathrm{~g}, 0.092 \mathrm{mmol})$ in $10 \mathrm{~mL}$ of $\mathrm{THF}$ cooled to $0^{\circ} \mathrm{C}$ was added $\mathrm{Ph}_{2} \mathrm{PMe}(17.20 \mathrm{ml}, 0.092 \mathrm{mmol})$ via a microsyringe. The red starting compound completely dissolved to yield a brown solution. The EPR spectrum showed a new resonance with Mo satellites at $g=1.947, a_{\mathrm{Mo}}=51.5 \mathrm{G}$. The EPR signal decreased in intensity and after $3 \mathrm{~h}$ the solution became EPR silent.

\section{Crystal structure determination of compound 3}

Crystal data. $\mathrm{C}_{57} \mathrm{H}_{53} \mathrm{BMoP}_{2} \mathrm{~S}_{2}, \mathrm{M}=970.80$, monoclinic, $a=18.943(2), b=12.397(1), c=$ 20.508(2) $\AA, \beta=91.138(7){ }^{\circ}, U=4815.1(8) \AA^{3}, T=293(2) \mathrm{K}$, space group $=P 2{ }_{1} / c$ (no. 14$), Z$ $=4, \mu=0.463 \mathrm{~mm}^{-1}, 8365$ reflections measured up to $\sin \theta / \lambda=0.59 \AA^{-1}, 8108$ unique $\left(\mathrm{R}_{\text {int }}=\right.$ 0.0302), which were used in all the calculations.

The data were corrected for absorption (psi-scan). ${ }^{43}$ No decay was observed. The structure was solved via a Patterson search program ${ }^{44}$ and refined (space group $P 2{ }_{1} / c$ ) with full-matrix leastsquares methods ${ }^{44}$ based on $\left|F^{2}\right|$. All non-hydrogen atoms were refined with anisotropic thermal parameters. Hydrogen atoms of the complex were included in their calculated positions and refined with a riding model. The cyclopentadienyl ligand was found to be disordered around its geometrical center and was modelled as lying in two positions with occupancies $\mathrm{m} 1=0.624$ and $\mathrm{m} 2=1-\mathrm{m} 1=0.376$. The cyclopentadienyl rings were refined as variable metric groups (the shape is retained but the group may shrink or expand uniformly). The final agreement indices are $R_{\mathrm{w}}\left(F^{2}\right)=0.0885$ and $R(F)=0.0987$ for all data and 600 parameters; $R(F)=0.0336$ for 5311 data with $I>2 \sigma(I)$; goodness of fit $=1.043$. The final Fourier difference map is featureless: $\Delta \rho$ $=0.335$ and -0.273 e $\AA^{-3}$.

CCDC reference number 186/1324. See http://www.rsc.org/suppdata/dt/1999/867/ for crystallographic files in .cif format.

\section{Acknowledgments}


We are grateful to the Conseil Régional de Bourgogne, the MENRT and the CNRS for support of this work. We also thank the Conseil Régional de Bourgogne and the II Plan Regional de Investigation del Principado de Asturias (Spain) for postoctoral fellowships to D. M.

\section{References}

$1 \quad$ R. R. Chianelli, Catal. Rev., Sci. Eng., 1984, 26, 361.

2 R. J. Angelici, Acc. Chem. Res., 1988, 21, 387.

3 T. B. Rauchfuss, Progr. Inorg. Chem., 1991, 39, 259.

4 E. I. Stiefel, D. Coucouvanis and W. E. Newton, (eds.), Molybdenum Enzymes, Cofactors, and Model Systems, Washington D.C., 1993.

$5 \quad$ E. I. Stiefel, J. Chem. Soc. Dalton Trans., 1997, 3915.

6 M. Rakowski DuBois, Chem. Rev., 1989, 89, 1.

7 M. Rakowski DuBois, Polyhedron, 1997, 16, 3089.

$8 \quad$ R. J. Angelici, Polyhedron, 1997, 16, 3073.

9 C. Bianchini and A. Meli, Acc. Chem. Res., 1998, 31, 109.

10 F. Y. Pétillon, P. Schollhammer, J. Talarmin and K. W. Muir, Coord. Chem. Rev., 1998, 178-179, 203.

11 S. T. Krueger, R. Poli, A. L. Rheingold and D. L. Staley, Inorg. Chem., 1989, 28, 4599.

12 S. T. Krueger, B. E. Owens and R. Poli, Inorg. Chem., 1990, 29, 2001.

13 R. Poli, S. T. Krueger, F. Abugideiri, B. S. Haggerty and A. L. Rheingold, Organometallics, 1991, 10, 3041.

14 R. Poli, B. E. Owens, S. T. Krueger and A. L. Rheingold, Polyhedron, 1992, 11, 2301.

15 R. Poli, B. E. Owens and R. G. Linck, Inorg. Chem., 1992, 31, 662.

16 R. Poli, B. E. Owens and R. G. Linck, J. Am. Chem. Soc., 1992, 114, 1302.

17 R. Poli, J. Coord. Chem. B, 1993, 29, 121.

18 R. Poli, Acc. Chem. Res., 1997, 30, 494, and references therein. 
19 J. Courtot-Coupez, M. Guéguen, J. E. Guerchais, F. Y. Pétillon, J. Talarmin and R. Mercier, J. Organomet. Chem., 1986, 312, 81.

20 M. B. Gomes de Lima, J. E. Guerchais, R. Mercier and F. Y. Pétillon, Organometallics, 1986, 5, 1952.

21 K. Hashizume, Y. Mizobe and M. Hidai, Organometallics, 1996, 15, 3303.

22 Z. Tang, Y. Nomura, Y. Ishii, Y. Mizobe and M. Hidai, Organometallics, 1997, 16, 151.

23 J. C. Fettinger, D. W. Keogh, B. Pleune and R. Poli, Inorg. Chim. Acta, 1997, 261, 1.

24 C. G. Screttas and J. F. Eastham, J. Am. Chem. Soc., 1966, 88, 5668.

25 R. Poli, Organometallics, 1990, 9, 1892.

26 J. Chatt, J. R. Dilworth, J. A. Schmutz and J. A. Zubieta, J. Chem. Soc., Dalton Trans., 1979, 1595.

27 J. C. Gordon, S. P. Mattamana, R. Poli and P. E. Fanwick, Polyhedron, 1995, 14, 1339.

28 B. E. Owens and R. Poli, Inorg. Chim. Acta, 1991, 179, 229.

29 R. C. Murray, L. Blum, A. H. Liu and R. R. Schrock, Organometallics, 1985, 4, 953.

30 F. Abugideiri, J. C. Gordon, R. Poli, B. E. Owens-Waltermire and A. L. Rheingold, Organometallics, 1993, 12, 1575.

31 R. Felsberg, S. Blaurock, S. Jelonek, T. Gelbrich, R. Kirmse, A. Voigt and E. HeyHawkins, Chem. Ber., 1997, 130, 807.

32 W. J. Geary, Coord. Chem. Rev., 1971, 7, 81.

33 E. Le Grognec, R. Poli and L.-S. Wang, Chem. Commun., submitted.

34 L.-S. Wang, J. C. Fettinger and R. Poli, J. Am. Chem. Soc., 1997, 119, 4453.

35 P. Schollhammer, E. Guenin, S. Poder-Guillou, F. Y. Petillon, J. Talarmin, K. W. Muir and P. Baguley, J. Organometal. Chem., 1997, 539, 193.

36 P. D. Grebenik, M. L. H. Green, A. Izquierdo, V. S. B. Mtetwa and K. Prout, J. Chem. Soc., Dalton Trans., 1987, 9.

37 K. Fromm and E. Hey-Hawkins, Z. Anorg. Allg. Chem., 1993, 619, 261. 
38 J. U. Desai, J. C. Gordon, H.-B. Kraatz, V. T. Lee, B. E. Owens-Waltermire, R. Poli, A. L. Rheingold and C. B. White, Inorg. Chem., 1994, 33, 3752.

39 J. C. Gordon, V. T. Lee and R. Poli, Inorg. Chem., 1993, 32, 4460.

40 R. G. Linck, B. E. Owens, R. Poli and A. L. Rheingold, Gazz. Chim. Ital., 1991, 121, 163.

41 D. N. Hendrickson, Y. S. Sohn and H. B. Gray, Inorg. Chem., 1971, 10, 1559.

42 S. Y. M. Chooi, T. S. A. Hor, P. H. Leung and K. F. Mok, Inorg. Chem., 1992, 31, 1494.

43 C. K. Fair, An Interactive Intelligent System For Crystal Structure Analysis, EnrafNonius, Delft, The Netherlands, 1990.

44 G. M. Sheldrick, SHELXS and SHELXL97, University of Gšttingen, Gšttingen, Federal Republic of Germany, 1997. 